University of Chicago Law School

Chicago Unbound

Journal Articles

Faculty Scholarship

1995

\title{
Response to Clark Freshman, Were Patricia Williams and Ronald Dworkin Separated at Birth?
}

Richard A. Posner

Follow this and additional works at: https://chicagounbound.uchicago.edu/journal_articles

Part of the Law Commons

\section{Recommended Citation}

Richard A. Posner, Response, "Response to Clark Freshman, Were Patricia Williams and Ronald Dworkin Separated at Birth?", 95 Columbia Law Review 1610 (1995).

This Article is brought to you for free and open access by the Faculty Scholarship at Chicago Unbound. It has been accepted for inclusion in Journal Articles by an authorized administrator of Chicago Unbound. For more information, please contact unbound@law.uchicago.edu. 


\section{BOOK REVIEW RESPONSE}

\section{RESPONSE TO CLARK FRESHMAN, WERE PATRICIA WILLIAMS AND RONALD DWORKIN SEPARATED AT BIRTH?}

\section{Richard A. Posner*}

An author's reply to a review of his book is rarely appropriate, but because I am called upon as a federal judge to deal with sensitive issues involving race and sex I do want to reply to the strong suggestion in Professor Freshman's review ${ }^{1}$ that my book Overcoming Law $^{2}$ is unfair to black and female scholars. In confining my reply to that aspect of the review, I do not mean to imply agreement with Freshman's other criticisins.

Freshman says that "Posner scrutinizes analytic philosophers, such as Rawls or Dworkin, for their thoughts, but examines [Patricia] Williams herself as if she were a specimen of some separate species. ${ }^{\text {"3 }}$ He says that I regard Williams as a "poseur," 4 and implies that I value her work in the same way that Socrates valued women "who "baked and boiled dishes." "5 By admiring the literary skills demonstrated in her book I am accused of reinforcing the stereotype of blacks as people who "tell good stories-at best, as great entertainers, and at worst, as untrustworthy scoundrels." 6 My book is "not fair because it treats Williams's work differently from that of other scholars, such as analytic philosophers like Dworkin, by pathologizing Williams the person and not examining her scholarship."7 I am said to dismiss Williams's work, and that of the radical feminist Catharine MacKinnon and the lesbian scholar Janet Halley, "as a product of their psychological disabilities or technical incompetence." 8 "[Posner] excludes their work from either serious debate or inquiry. Instead, Posner pathologizes the women themselves." In the chapter on Martha Minow my book "deploys words more typical of an elementary school girl's report card than a review of the work of a tenured professor at Harvard Law

* Chief Judge, United States Court of Appeals for the Seventh Circuit; Senior Lecturer, University of Chicago Law School.

1. Clark Freshman, Were Patricia Williams and Ronald Dworkin Separated at Birth?, 95 Colum. L. Rev. 1568 (1995) (Review of Richard A. Posner, Overcoming Law (1995)).

2. Richard A. Posner, Overcoming Law (1995)

3. Freshman, supra note 1 , at 1572 (citations omitted). Williams, a hlack law professor, is the author of The Alchemy of Race and Rights (1991), which I discuss in Chapter 18 of Posner, supra note 2 ("Nuance, Narrative, and Empathy in Critical Race Theory").

4. Freshman, supra note 1 , at 1573 .

5. Id. at 1575 .

6. Id.

7. Id. at 1607.

8. Id. at 1587 n.70.

9. Id. at 1589 (citation omitted). 
School."10 I am said to deny "the individuality of Williams and other scholars of color," a treatment that resembles the treatment of "supposedly lower life forms."11 Indeed, it seems that I deny these scholars' very "humanity."12 According to Freshman, I "cannot even read what they write."13 And he says that I attribute some unnamed "disorder" to Catharine Mackinnon and imdeed write as if "only women authors have psychological-or perhaps emotional-lives."14 And on and on in this vein. In short, I am accused of employing a vicious double standard in which white males are treated respectfully and women and blacks disrespectfully, even barbarously.

I might be able to refute this accusation either by showing that I treat white males disrespectfully or by showing that I treat women and blacks respectfully. I ani naturally reluctant to take the first of these roads, and so will merely note that one of my (and Professor Strauss's) academic colleagues in a letter called my criticism of Strauss's article on the DeShaney case "dumb rhetoric," that Walter Berns, the white male whose view of constitutional law I criticize in Chapter 8, wrote a letter to the New Republic (where the chapter was first published) accusing ine of gross unfairness and questioning my fitness to be a judge, so unfairly had I treated him, and that Professor Jaffee, the white male whose anarcho-vegetarian philosophy I criticize with some asperity in Chapter 12,15 probably does not have warm feelings for me either. In that chapter I explicitly ascribe to Jaffee, a white male, the same lack of a "tight grip on the world of fact"16 that Freshman accuses me of ascribing to Minow because she is a woman, and I explicitly classify Minow with the white scholars whom I discussed in a previous chapter. ${ }^{17}$

I would prefer to think that I treat all scholars with whose views I disagree fairly and respectfully, if not always accurately or cogently, and I note that Freshman does not suggest that I am unfair to most of the women whose ideas I discuss critically in Overcoming Law, such as Linda Hirshman, Martha Nussbaum, and Margaret Radin, even though all are feminist scholars rather than bakers or boilers of dishes. I respect Janet Halley too; I simply disagree with her evaluation of the scientific evidence

10. Id. at 1590. These words are that "Minow is intelligent, conscientious, hardworking," but "does not have a tight grip on the world of fact." Id. at 1590 n.82, (quoting Posner, supra note 2, at 294, 298).

11. Id. at 1591.

12. Id. at $1591 \mathrm{n} .86$.

13. Id. at 1591. Only one example of this incapacity is given: I wrote that the Stanford student who disbelieved (correctly) that Beethoven was a black man may simply have been "incredulous" at the idea, whereas the official report of the incident by the Stanford administration said that the student had thought the idea "preposterous." See id. at 1573 n.20.

14. Id. at 1592.

15. See Posner, supra note 2, at 295-98.

16. Id. at 298.

17. See id. at 294. 
that sexual orientation is innate rather than acquired. I respect Catharine Mackinnon, as should be evident from comments in my book about her place in modern legal scholarship. ${ }^{18}$ But I also think that her book about pornography is fairly described as I described it-“a verbal torrent that, much like pornography itself as Mackinnon conceives of it, appeals to elemental passions (fear, disgust, anger, hatred) rather than engaging the rational intellect."19

And I respect Patricia Williams. I certainly do not regard her as a poseur, or as a member of a different species from Rawls and Dworkin. What Freshman fails to see is that because Williams is engaged in a different genre of scholarship from Rawls and Dworkin, the critique of her work is bound to take a different form. Rawls and Dworkin are analytic philosophers; I have much to say about this genre of scholarship in my book, most of it highly critical. ${ }^{20}$ Williams is not an analytic philosopher. She is a narratologist. Her book is a compendium of stories about her own life (hence the subtitle, "Diary of a Law Professor," which appears on the paperback edition of the book). The genre in which she works is utterly different from the genre in which Rawls and Dworkin work, and it invites different criticisms. The weakness of analytic philosophy is its frequent aridity. The weakness of narratology is its uncertain relationship to fact, and I gave illustrations from her book. (Maybe I dwelt too long on the question whether Beethoven was black, but I found it weirdly fascinating.) I said-a related point-that I thought her book one-sided, but in saying this 1 paid her what 1 thought was the supreme compliment of putting her in the same company with William Shakespeare, Charles Dickens, and Henry James-great writers (male, by the way) who were, nevertheless, incapable of grasping certain poimts of view. ${ }^{21}$ My criticisms were of a genre dommated by white males. I do not think that a fairminded reader of my chapter about Williams would doubt that I admired her book.

I wonder whether black and female scholars will be grateful to Professor Freshman for rushing to their defense against me. I suspect not. Freshman's subtext is that any white male who criticizes a black, feminist, or lesbian scholar is presumed to be doing so in bad faith. The response of many white males will be to give those forms of scholarship a wide berth, thus ghettoizing them. I doubt whether they will benefit from that benign neglect.

18. See id. at 86,99 .

19. Id. at 357. On the first page of her text, for example, we read that "[y]ou grow up with your father holding you down and covering your mouth so another man can make horrible searing pain between your legs. When you are older, your husband ties you to the bed and drops hot wax on your nipples and brings in other men to watch and make you smile through it." Catharine A Mackinnon, Only Words 1 (1993).

20. See Posner, supra note 2, at chs. $5 \& 22$.

21. See id. at 380 . 